\title{
Seasonal age distributions and maturity stage in a naturalized rainbow trout (Oncorhynchus mykiss Walbaum) population in southern Chile reveal an ad-fluvial life history
}

\author{
Ivan Arismendi ${ }^{1,2 *}$, Jose Sanzana $^{3}$ and Doris Soto ${ }^{4}$ \\ ${ }^{1}$ Escuela de Graduados, Facultad de Ciencias Forestales, Universidad Austral de Chile, Casilla \#567 Valdivia, Chile \\ 2 Current address: Department of Geosciences, Oregon State University, 3200 SW Jefferson Way, Corvallis, OR 97331, USA \\ 3 Darwin Initiative, Laboratorio de Genética, Acuicultura y Biodiversidad, Universidad de Los Lagos, Avenida Fuschlocher 1305, \\ Osorno, Chile \\ ${ }^{4}$ Inland Water Resources and Aquaculture Service (FIRI), Fisheries Department, FAO of United Nations, Via delle Terme \\ di Caracalla, 00100 Rome, Italy
}

Received 21 April 2010; Accepted 4 January 2011

\begin{abstract}
Rainbow trout is one of the most popular introduced game species around the world. Similar patterns of use for lake and inlet streams have been described for both native and introduced populations. However, for many introduced rainbow trout populations, there is a lack of information about how and when those habitats have been used. Here, we hypothesized that the majority of adult and sexually mature individuals inhabit inlet streams during the reproductive period most likely to spawn whereas juvenile trout occupy these same streams as nursery areas most of the year before emigrating to the lake. We studied rainbow trout age distribution and sexual maturity in a lake and its main inlet streams in southern Chile. We found that stream-dwelling individuals inhabited inlet streams up to age $2^{+}$whereas lake-dwelling trout were older (most of them from ages $4^{+}$to $6^{+}$). During the reproductive period (May to September) older and sexually mature individuals were in both habitats probably indicating movement to upstream locations to spawn. Rainbow trout of the same ages were larger in the lake than in streams, which may imply better growth in the lenthic environment. Our study offers further evidence of the highly adaptable nature of rainbow trout. Future regulations should consider rainbow trout populations in lakes and streams separately because trout life histories suggest that both environments are important to different ontogenic stages. This study provides key information that may be useful in the management of ad-fluvial populations of rainbow trout in Patagonia.
\end{abstract}

Key words: Oncorhynchus mykiss / habitat use / sport fishing / partial migration / trout management

\section{Introduction}

Freshwater fish introductions are mostly driven by taxonomically biased human interests (Marr et al., 2010). Rainbow trout (Oncorhynchus mykiss Walbaum) is one of the most popular game species that has been introduced all over the world (Crawford and Muir, 2008). Similar patterns of habitat use have been reported in both native and introduced populations, with adults using inlet streams to spawn and juveniles occupying streams as nursery areas before they emigrate to the lake (Youngs and Oglesby, 1972; Hayes, 1988; Rosenau, 1991; Seelbach, 1993; Sakai and Espinos, 1994; Graynoth, 1996; Dedual et al., 2000; Riva-Rossi et al., 2007). However, naturalized

\footnotetext{
*Corresponding author: Ivan. Arismendi@oregonstate.edu
}

populations currently exist across a diverse array of habitats (Crawford and Muir, 2008). In many cases, such as southern Chile (Soto et al., 2006; Arismendi et al., 2009), there is a lack of information about how rainbow trout use these habitats. Rainbow trout in southern Chile have been identified in various sections of headwater streams and in almost all of the 25 or more great temperate Araucanian lakes $\left(39^{\circ}-43^{\circ} \mathrm{S}\right.$; Thomasson, 1963) in the region (Soto et al., 2006). Rainbow trout have been introduced to Chile for both recreational fishing (1890s) and modern salmon aquaculture (1980s) purposes (Basulto, 2003). The rainbow trout introduced for aquaculture have been placed in several Araucanian lakes, and due to storms, faulty nets, and human error they have escaped from net pens and are now free-living in the environment (Basulto, 2003; Arismendi et al., 2009). 

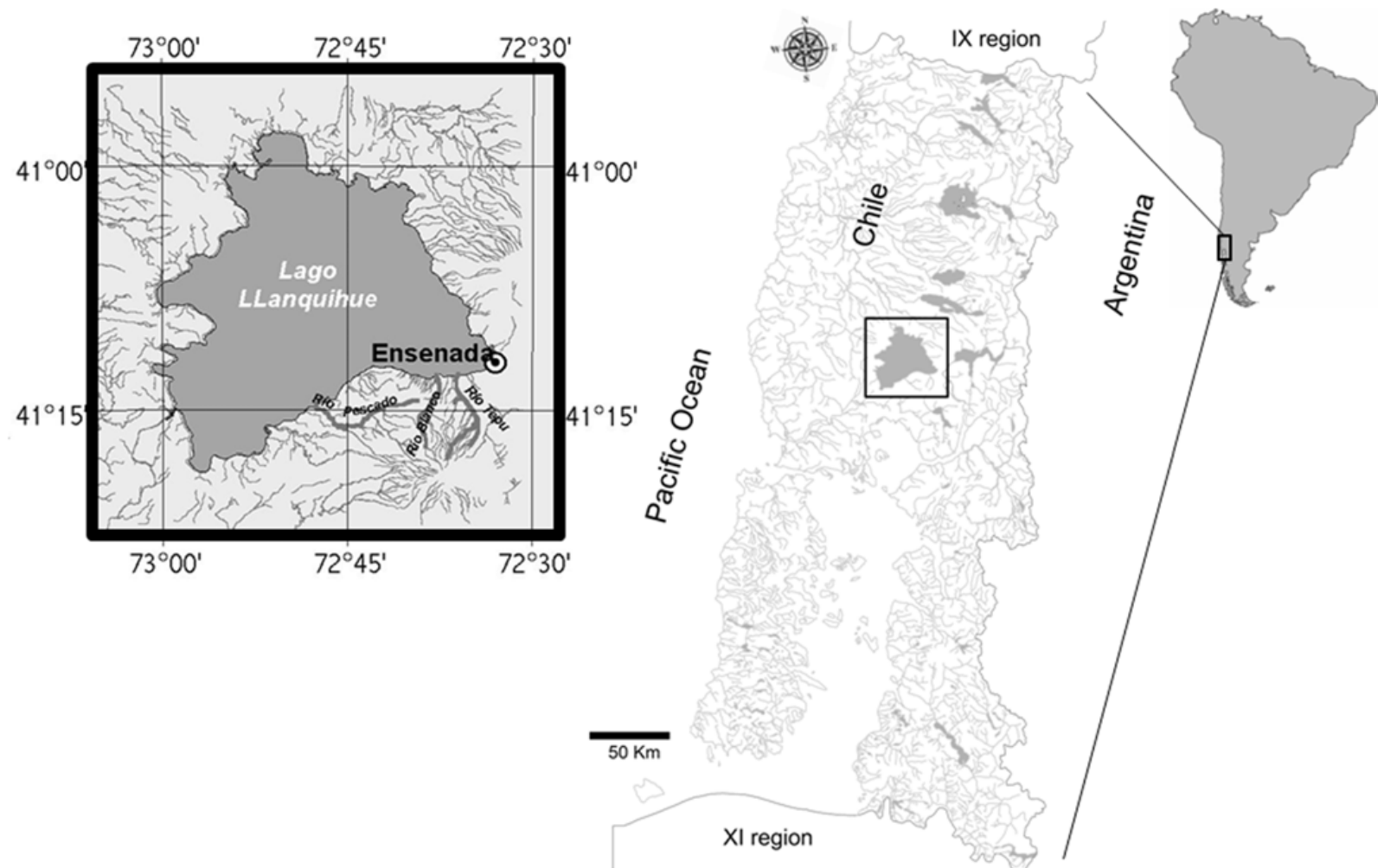

Fig. 1. Study area enlargement of the Lakes District and Lago Llanquihue including the main inlet streams (Pescado, Blanco, and Tepu).

Nevertheless, fundamental questions about the population structure of rainbow trout in this region remain unknown.

In this study, we report the seasonal age distribution, length at age, and spawning period of rainbow trout in Lago Llanquihue and its three main inlet streams in southern Chile. Our objectives are to identify the relative occupancy of various age-classes in the lacustrine and fluvial environments during the reproductive and nonreproductive periods to provide basic biological information for adequate management. We predict that rainbow trout, as seen in native and invaded ecosystems, are younger aged in the inlet streams and older aged in the lake. But, during the reproductive period, we expect that the inlet streams and lake shore will contain mature and older-aged trout. This would provide indirect evidence that rainbow trout use both inlet streams and the lake with potential seasonal movement between them. If our prediction is supported, then our study would provide baseline population and life-history strategy information that are needed to effectively manage rainbow trout and to develop a theoretical framework for predicting the potential invasion of trout in southern Chile.

\section{Material and methods}

\section{Study area}

Our study sites, Lago Llanquihue and its three main inlet streams, are located in the Lakes District, X Region of southern Chile (Fig. 1). In this area, the climate is temperate with an annual range of precipitation between 130 and $220 \mathrm{~cm}$. Lago Llanquihue is the second-largest lake in the southern part of South America (Campos et al., 1988) and has characteristics that are common to all Araucanian lakes (a) glacial origin with volcanic influence in the soils; (b) very deep $\left(Z_{\max }>100 \mathrm{~m}\right)$; (c) monomictic with thermal stratification in the summer; (d) high in water transparency; and (e) oligotrophic with very low salt/nutrient and chlorophyll- $a$ concentrations (see Table 1 for more details). Rainbow trout share the pelagic waters of Lago Llanquihue with several native fishes such as Galaxias maculatus Jenyns, Galaxias platei Steindachner, silversides Odontesthes mauleanum Steindachner and Basilichthys australis Eigenmann, and the other introduced salmonids Oncorhynchus kisutch Walbaum, Oncorhynchus tshawytscha Walbaum, Salmo salar Linnaeus, and Salmo trutta Linnaeus (Soto et al., 2006).

The three main inlet streams, Pescado, Blanco, and Tepu, are third-order streams located on the southern shore of the lake and they originate on the slopes of the Calbuco volcano between 1000 and $1600 \mathrm{~m}$ of altitude. Lago Llanquihue receives almost half of its water input from the three studied streams, with the other half being provided by rainfall (Campos et al., 1988). No other streams connect to the study sections of these streams, and the downstream study boundaries in the streams were located 5-8 km upstream of the lake. There are no barriers to fish movements between the study boundaries in the inlet streams and the lake. Other inlet streams were not 
Table 1. Environmental characteristics of Lago Llanquihue and the three inlet streams.

\begin{tabular}{|c|c|c|c|c|}
\hline & Lago Llanquihue & Pescado & Blanco & Tepu \\
\hline Altitude (m a.s.1.) & 51 & & & \\
\hline Area $\left(\mathrm{km}^{2}\right)$ & 87.5 & & & \\
\hline Volume $\left(\mathrm{km}^{3}\right)$ & 158.6 & & & \\
\hline Shoreline $(\mathrm{km})$ & 196.4 & & & \\
\hline Mean depth (m) & 182 & & & \\
\hline Water renewed (years) & 74 & & & \\
\hline Drainage area $\left(\mathrm{km}^{2}\right)$ & 1605 & 78 & 28.5 & 32 \\
\hline Length $(\mathrm{km})$ & & 20 & 14 & 18 \\
\hline Average monthly runoff $\left(\mathrm{m}^{3} \cdot \mathrm{s}^{-1}\right)$ & & 4.9 & 1.8 & 2 \\
\hline Range of transparency $(\mathrm{m})$ & $14.0-21.0$ & & & \\
\hline Temperature range in epilimnion $\left({ }^{\circ} \mathrm{C}\right)$ & $14.0-18.5$ & & & \\
\hline Temperature range in hypolimnion $\left({ }^{\circ} \mathrm{C}\right)$ & $10.4-10.9$ & & & \\
\hline Range of depth in thermocline (m) & $37-50$ & & & \\
\hline Range of temperature $\left({ }^{\circ} \mathrm{C}\right)$ & & $6.2-12.8$ & $7.5-9.9$ & $7.8-11.2$ \\
\hline Range of $\mathrm{pH}$ & $6.7-8.4$ & $6.5-7.8$ & $5.8-7.6$ & $7.0-8.0$ \\
\hline Range of conductivity $\left(\mu \mathrm{S} . \mathrm{cm}^{-1}\right)$ & $92-128$ & $19-36$ & $50-60$ & $35-77$ \\
\hline Range of $\mathrm{NO}_{3}-\mathrm{N}\left(\mu \mathrm{g} . \mathrm{L}^{-1}\right)$ & $1-67$ & $2-51$ & $2-24$ & $2-65$ \\
\hline Range of $\mathrm{PO}_{4}-\mathrm{P}\left(\mu \mathrm{g} . \mathrm{L}^{-1}\right)$ & $0.1-3.9$ & $2.9-21.4$ & $2.9-21.3$ & $2.9-21.3$ \\
\hline
\end{tabular}

Source: Niemeyer and Cereceda (1984); Campos et al. (1988).

considered in this study because of their small size, but they have similar hydrological characteristics to the three studied inlet streams (Niemeyer and Cereceda, 1984).

\section{Data collection}

We collected fish data bimonthly in Lago Llanquihue and monthly in the three inlet streams from December 2000 through November 2001. At each sampling time we measured the total length (TL) (to the nearest $\mathrm{cm}$ ) of all captured rainbow trout. In the lake, we used two experimental gill nets that were $280 \mathrm{~m}$ long and $3.5 \mathrm{~m}$ deep varying mesh sizes $(3.81,7.62,12.06$, and $15.24 \mathrm{~cm})$. Our nets were designed and tested to capture fishes over $10 \mathrm{~cm}$ of TL (Palma, 1996). Also, because rainbow trout swim closer to the littoral zone in the epilimnion (Palma, 1996) we positioned the nets at the surface and perpendicular to the shoreline of the lake beginning at the water's edge. We checked the nets every $4 \mathrm{~h}$ for up to $48 \mathrm{~h}$. Since there was a low selectivity of gill nets toward smaller-sized trout, we made observations around the nets every $4 \mathrm{~h}$ to indicate the presence/absence of trout less than $10 \mathrm{~cm}$ TL. For each inlet stream, we sampled a $400 \mathrm{~m}$ reach using twopass backpack electrofishing with a uniform time effort of $1.5 \mathrm{~h}$. stream $^{-1}$. In order to account for different-sized fish, we sampled in all available habitat units (pool-run-riffle) and to ensure our catch per unit effort (CPUE) accuracy we used the same electrofishing operator in similar flow conditions during the study. We used CPUE (gill netting was trout. $\mathrm{h}^{-1}$, electrofishing was trout. $\mathrm{m}^{-2}$ ) as an index of abundance. Since streams had relatively high flows and were large in size (third-order streams; see Table 1), we were unable to enclose the reaches during the sampling procedures. However, we selected reaches that had natural barriers (e.g., small waterfalls) at the starting and ending of sampling locations so that fishes could not move easily outside of the sampling area.

\section{Age estimation and maturity}

To age trout, we identified annuli with the conventional technique used in the Northern Hemisphere (Chugunova, 1959; Davis and Light, 1985) of assigning crowding of inter-circuli distances associated with a slow growth typical during winter. This technique has been used in rainbow trout populations of New Zealand (e.g., Graynoth, 1996) and the Argentinean Patagonia (e.g., Pascual et al., 2001; Riva-Rossi et al., 2007). Scales were removed from an area below the posterior margin of the dorsal fin and approximately five scale rows above the lateral line (Pascual et al., 2001; Riva-Rossi et al., 2007). We discarded any resorbed, abnormal, regenerated scales from analysis. We counted the number of scale annuli from five scales per fish. For the scale analysis, we subsampled trout by size defining the size class according to previous length records of rainbow trout in Lago Llanquihue (Palma, 1996). We included eight size classes every $10 \mathrm{~cm}$ of TL and randomly selected a minimum of five trout in each size class. We classified these subsampled trout as "lake dwelling" (captured from Lago Llanquihue; $n=46$ ) and "stream dwelling" (captured from the three inlet streams; $n=96$ ). We sub-sampled trout for scale analysis during the non-reproductive period (October to April; Soto et al., 2002) because the possible trout movement from the lake to the inlet streams during the reproductive period could increase the potential overlap between "lake-dwelling" and "stream-dwelling" trout. To read the scales, we used a microfiche projector, Model II Mini Cat, with a $22 \mathrm{~mm}$ lens under $42 \times$ magnification. We examined scale ages twice using two experienced readers to ensure consistency. We assigned age to the rest of the captured trout, during all seasons, according to Isermann and Knight (2005) differentiating between "lake dwelling" and "stream dwelling". Additionally, from sub-sampled trout we back-calculated the trout size at the annulus formation according to the Fraser 
(1916) and Lee (1920) method with a $43 \mathrm{~mm}$ (length at squamation) correction factor (Rabe, 1967). Since we did not find great differences on spaced circuli between annuli (see Davis and Light, 1985), we did not consider the occurrence of anadromy.

We also obtained a sub-sample of rainbow trout from the lake and inlet streams and identified their sex and maturity stage using direct observation of the gonads (Soto et al., 2002). In males, an individual was classified as mature when its white testicles extended up to, at least, two-thirds of the abdominal cavity. For females, an individual was considered mature when it had ovaries of an intense orange color with well-developed eggs, or transparent ovaries that occupied up to two-thirds of the abdominal cavity.

\section{Data analysis}

To compare the age distribution among "streamdwelling" and "lake-dwelling" trout during the reproductive period (May to September; Soto et al., 2002) and the non-reproductive period, we utilized a non-parametric Kolmogorov-Smirnov two-sample test. Additionally, to test differences on back-calculated length-at-age between "stream-dwelling" and "lake-dwelling" trout we used an analysis of covariance (ANCOVA). We defined the backcalculated length as the dependent variable, and the backcalculated age as the covariate under the null hypothesis of no difference between "stream-dwelling" and "lakedwelling" trout for the slope of the length-at-age regressions. For the ANCOVA test, we set $\alpha$ at 0.05 and the homogeneity of variances and normal distribution assumptions were met after both the independent and dependent variables were log transformed.

\section{Results}

We captured a total of 1613 rainbow trout from the inlet streams with a CPUE ranging from 0.05 to 0.56 trout. $\mathrm{m}^{-2}$ with a mean of 0.24 trout. $\mathrm{m}^{-2}$ and a mean trout size of $10.8 \mathrm{~cm}$. Among the streams, Tepu had the greatest CPUE (mean of 0.37 trout. $\mathrm{m}^{-2}$ ) followed by Blanco and Pescado (0.21 trout. $\left.\mathrm{m}^{-2}\right)$, but the medians of the trout size $\left(\mathrm{Tepu}_{\text {median }}\right.$ length $=8.0 \mathrm{~cm}$, Blanco $_{\text {median length }}=9.3 \mathrm{~cm}$, and Pescado median length $=$ $8.0 \mathrm{~cm}$ ) and age (all streams with a median age of $1^{+}$) were not different $(P>0.7)$. Also, more than $95 \%$ of the trout captured in the inlet streams were between 2 and $20 \mathrm{~cm} \mathrm{TL}$ or aged from $0^{+}$to $2^{+}$with a peak age $0^{+}$occurring in the summer and the maximum age found in the winter (age $11^{+}$; Fig. 2). In the lake, we captured a total of 166 rainbow trout with a CPUE that ranged from 0.41 to 1.0 trout. $\mathrm{h}^{-1}$ with a mean of 0.67 trout. $^{-1}$ and a mean trout size of $40.7 \mathrm{~cm}$. Almost $99 \%$ of trout were over $20 \mathrm{~cm}$ and over $2^{+}$(Fig. 2), with the greatest proportion between ages $4^{+}$and $6^{+}$. Spring was the only season when we captured trout of age $2^{+}$in the lake.

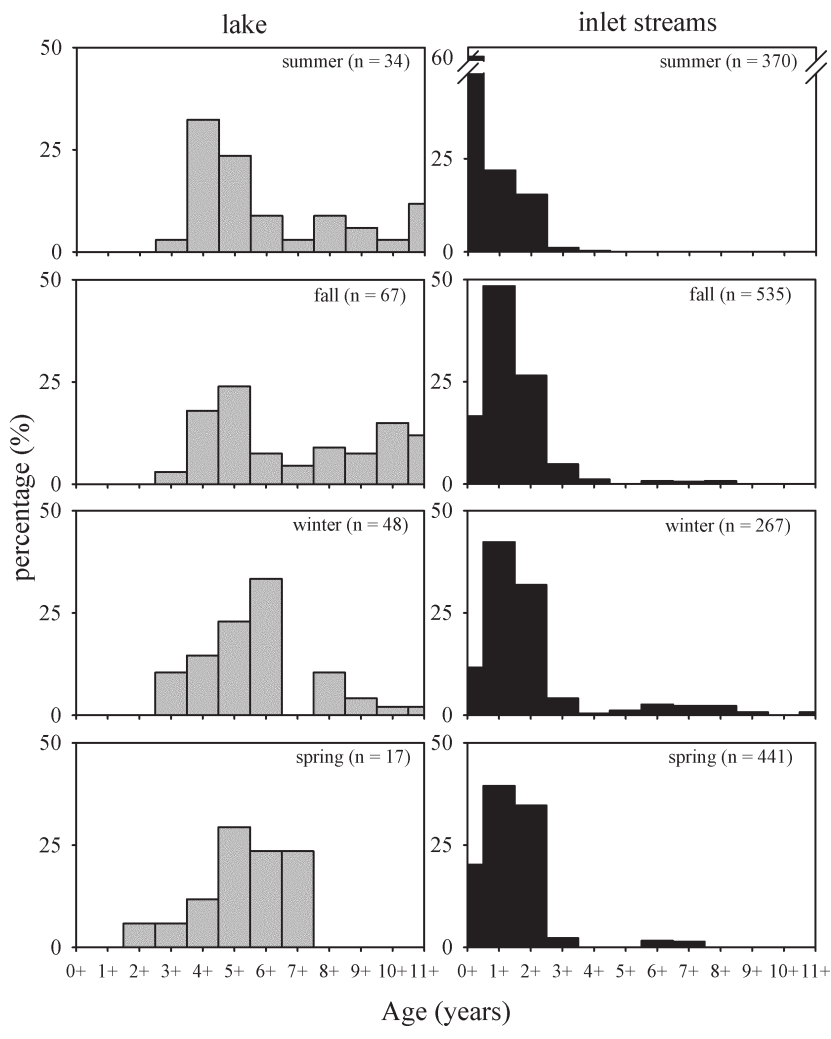

Fig. 2. Percentage of rainbow trout captured from 2000 to 2001 in Lago Llanquihue and its inlet streams (Pescado, Blanco, and Tepu) grouped by age and period. Lake-dwelling rainbow trout (gray); stream-dwelling rainbow trout (black).

We found significant differences in the age of trout from streams and the lake during both non-reproductive (median age $_{\text {lake }}=4.9$ years and median age $_{\text {streams }}=$ 1.14 years; $\mathrm{K}-\mathrm{S}$ test $P<0.001)$ and reproductive periods (median age $_{\text {lake }}=6.17$ years and median age streams $=$ 1.37 years; $\mathrm{K}-\mathrm{S}$ test $P<0.001)$. In streams during the reproductive period, we found rainbow trout older than age $3^{+}\left(57 \%\right.$ were trout of age $\left.6^{+}\right)$and during winter and spring more than $60 \%$ of all trout older than age $3^{+}$were trout over age $5^{+}$. During the non-reproductive period the most common ages in the streams were $0^{+}$to $1^{+}(70 \%)$, showing a significant difference from those during the reproductive period $(\mathrm{K}-\mathrm{S}$ test; $P<0.005)$. Similarly, in lakes we found significant differences $(\mathrm{K}-\mathrm{S}$ test; $P<0.001)$ in the age of trout captured during the reproductive $(68 \%$ were age $\left.6^{+}\right)$and non-reproductive periods $(72 \%$ were older than $5^{+}$). From a total of 285 rainbow trout, in which sex and maturity were determined, $53 \%$ were female, $47 \%$ were male, and $58 \%$ were sexually mature (Fig. 3). The greatest proportion of sexually mature individuals (ages $4^{+}$to $11^{+}$) was captured in winter $(35 \%)$ and spring $(15 \%)$.

We found no significant differences in the slope of the length-at-age regressions between "stream-dwelling" and "lake-dwelling" trout (ANCOVA; Fig. 4). However, we found significant differences in the length of trout between 


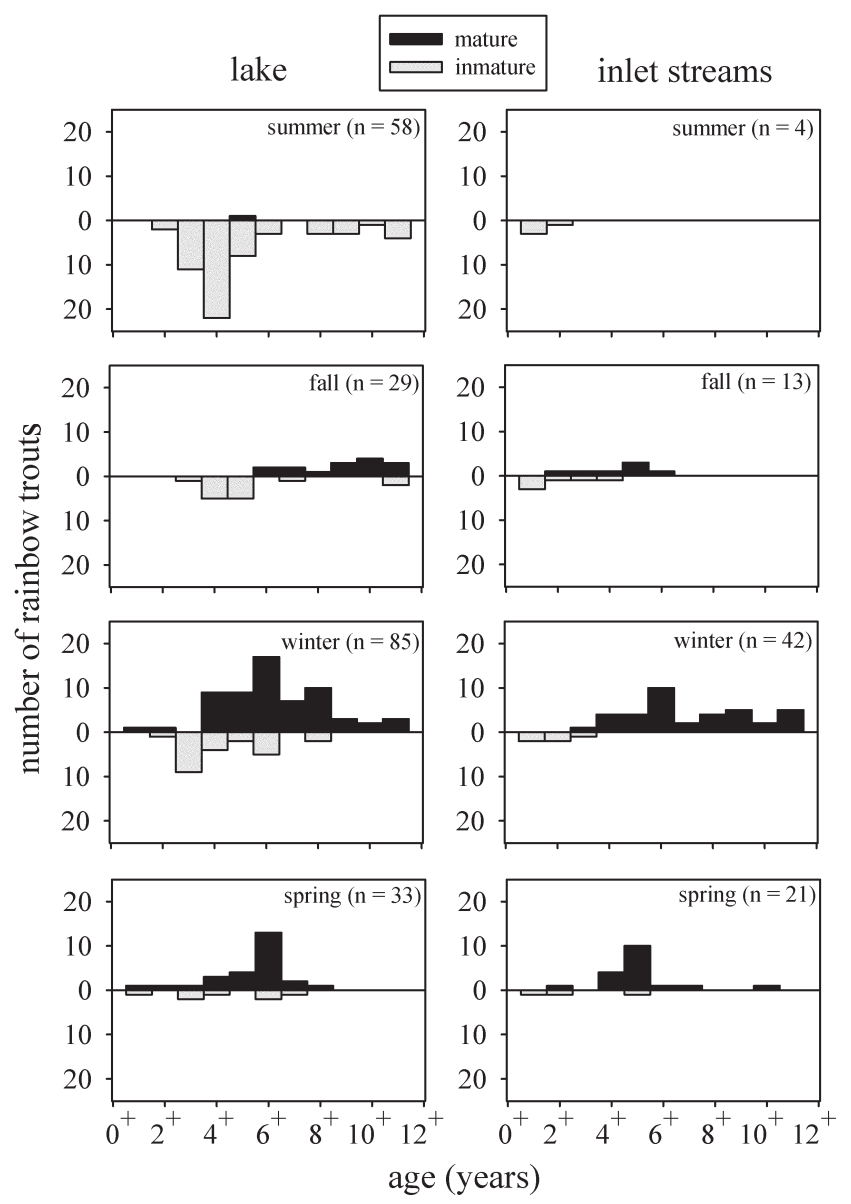

Fig. 3. Occurrence of mature (black) and immature (gray) rainbow trout in Lago Llanquihue and its inlet streams (Pescado, Blanco, and Tepu) grouped by age and period.

lake- and stream-dwelling fishes when age was kept constant $\left(F_{1500}=67.6 ; P<0.01\right)$. Trout of age 2 in both the lake and inlet streams had a similar back-calculated size $(11 \mathrm{~cm}$ in streams and $12 \mathrm{~cm}$ in the lake), but trout of age 7 were $47 \mathrm{~cm}$ in the lake and $40 \mathrm{~cm}$ in streams.

\section{Discussion}

Our study shows that in our study lake-inlet system of southern Chile ad-fluvial rainbow trout use streams and lakes throughout their life history. Stream-dwelling rainbow trout up to age $2^{+}$inhabit streams and are apparently absent in the lake except in spring, whereas lake-dwelling rainbow trout are most frequent in the lake over age $2^{+}$and consist mostly of ages $4^{+}$to $6^{+}$. These results suggest that in our study lake-inlet system, as seen in their native distribution (Northcote, 1997; Quinn and Myers, 2004) and in other naturalized populations in both eastern North America (Youngs and Oglesby, 1972; Seelbach, 1993) and New Zealand (Hayes, 1988; Rosenau, 1991; Graynoth, 1996), most of the rainbow trout spend 1-2 years in the inlet streams and then move

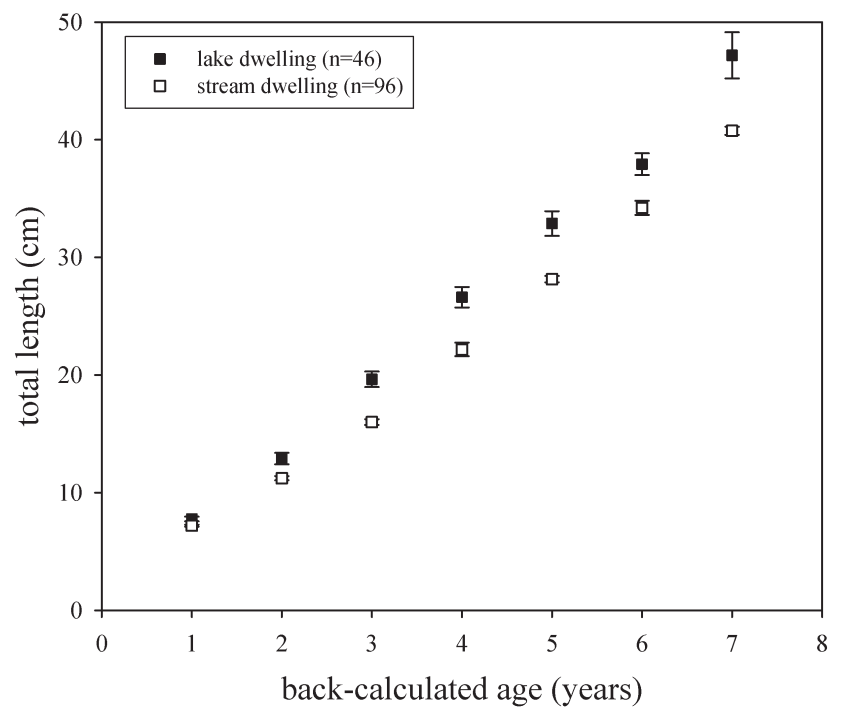

Fig. 4. Size (TL; cm) at age of rainbow trout in Lago Llanquihue and its inlet streams based on back-calculated lengths at age. Boxes represent mean $\pm \mathrm{SE}$ and include lake-dwelling rainbow trout (black) and stream-dwelling rainbow trout (white).

downstream to the lake. Thus, our study provides basic information that confirms the life-history strategies seen elsewhere in other ad-fluvial naturalized $O$. mykiss populations.

Our study is limited by the low selectivity of our gill nets toward smaller-sized and probably younger trout, and consequently we may underestimate the presence of age $1^{+}$and younger trout in the lake. However, it seems unlikely that smaller-sized trout are present along the surface of the littoral zone because as we checked gill nets, every $4 \mathrm{~h}$, we made direct observations around the nets and did not notice the presence of small trout. Similarly, other studies in comparable lakes of southern Chile do not report the presence of smaller-sized trout; rather they report size distributions comparable to our results from Lago Llanquihue (Soto et al., 2001, 2002). In addition, indirect evidence from previous stomach analysis of large salmonids in Lago Llanquihue captured in this zone shows no detection of small trout as prey (Arismendi et al., 2009). We encourage future lake research to include additional sampling techniques (e.g., beach seining, fyke nets, snorkeling) to address the potential importance of smallersized trout.

The presence of younger trout (age $2^{+}$) in the lake during spring may be a result of the timing of lakeward dispersal from the inlet streams, similar to what is seen in British Columbia (Northcote, 1962; Mellina et al., 2005). The selection of specific habitat, such as inlet streams or a lake, by rainbow trout depends on habitat suitability (e.g., growing areas), food abundance, and growth rates (Northcote, 1992; Quinn and Myers, 2004; Satterthwaite et al., 2010). The habitat in the lake may be more suitable than the inlet streams in the spring due to favorable temperatures in the epilimnion (see Table 1). In addition, there is higher aquatic insect biomass in Lago Llanquihue 
(Chironomidae, Mollusca, Oligochaeta, Hirudinea, Amphipoda, and Isopoda ranging from 5.8 to $409.1 \mathrm{~g} . \mathrm{m}^{-2}$ with a mean of 194 g.m ${ }^{-2}$ ) than in the three inlet streams (Chironomidae, Ephemeroptera, Diptera, Plecoptera, and Trichoptera ranging from 0.78 to 13.6 g.m ${ }^{-2}$ with a mean of 5.1 g.m ${ }^{-2}$ ) with the spring having the lowest densities and biomass seasonally in the inlet streams (Campos, 1986). Thus, it is possible that younger rainbow trout may move from the inlet streams to areas with more favorable conditions in the lake during springtime.

Additionally, our study shows that trout of the same age captured in the lake were bigger than trout in the inlet streams, which may be a reflection of better habitat suitability and food availability. However, the growth of lake-dwelling trout seems to be slow when compared with New Zealand (Rosenau, 1991; Graynoth, 1996) possibly due to the trout population being above carrying capacity as suggested by Arismendi et al. (2009). We suggest that future research focus on younger fishes to examine the timing and magnitude of seasonal movement patterns. The use of bioenergetic models could be useful in the examination of movement patterns and growth rates in the inlet streams and lake.

The presence of older mature trout during the reproductive period (fall-winter) over the rest of the year results in a change in the age distribution in the lake and inlet streams. Older lake-dwelling mature trout may move from pelagic zones to the shoreline of the lake and then go upstream to the inlet streams to spawn (e.g., Seelbach, 1993). In accordance with our results, Soto et al. (2002) reported, for our study lake-inlet system, a higher frequency of larger mature (and probably older) rainbow trout in the lake and its inlet streams from May to October, with a peak in July and August. Dedual et al. (2000) reported similar results in New Zealand. Movements of rainbow trout from the lake into its inlet streams to spawn have also been described widely in the Northern Hemisphere (Behnke, 1992; Crawford, 2001), New Zealand (Rosenau, 1991; Dedual et al., 2000), but only in one study in South America, southern Argentina (Sakai and Espinos, 1994). Also, the wide period of time during which older trout (probably the bulk of spawners) are present in the inlet streams may reflect a spawning period that extends until late spring. Furthermore, it would indicate that the spawning occurs mainly in winter and spring as the frequency of age $0^{+}$trout in streams peaks in summer. Some trout may start to disperse toward their spawning streams in the fall months before they spawn (e.g., Sakai and Espinos, 1994) and/or may also stay in the streams months after the completion of spawning (e.g., Dedual et al., 2000). As a consequence, older trout are not found along the shoreline of the lake during spring because they are probably still spawning or, if they are spent, they may be waiting for a freshet to push them back into the lake.

Additionally, the presence of older and mature trout (aged from $5^{+}$to $8^{+}$) in the inlet streams during the reproductive period may be an indicator of repeat spawners, as reported in their native range (Lindsay et al., 1959) and in naturalized populations such as southern Argentina (Sakai and Espinos, 1994; Riva-Rossi et al., 2007), suggesting the presence of an iteroparous population in Lago Llanquihue. On the other hand, the proportion of trout $\left(2^{+}\right.$to $\left.4^{+}\right)$observed in the streams during summer may indicate protracted rearing periods for some trout or that some individuals spend their entire lives in these streams as seen in British Columbia (Mellina et al., 2005).

Our study provides basic biological information on rainbow trout populations that will be helpful in the creation of new management strategies. Accurate information on the age and maturity stage of trout is needed for the conservation and management of stocks. Rainbow trout is a target species for recreational fishing in Chile and Lago Llanquihue has been historically a top destination generating between three and five million US dollars/year of spending (Arismendi and Nahuelhual, 2007). In the last four decades, recreational fisheries regulations in Chile have been somewhat static and mainly consider (1) a regional scale with lakes and streams treated equally, (2) salmon and trout species being grouped together, (3) a daily bag limit (two trout per fishing day) with a minimum fish take size (>30 cm TL), and (4) a prohibition on angling during the trout spawning season (May-November). Based on our study, we recommend that future regulations consider rainbow trout populations in lakes and streams separately because their life-history strategy suggests that both water bodies are important to different ontogenic stages and at different times of the year. Our study also indirectly suggests that rainbow trout appear to be successfully reproducing in the wild, which brings up the question about whether fisheries managers want to review the current regulations about continued stocking of rainbow trout (e.g., escapes from aquaculture facilities, stocking) to prevent exceeding sustainable salmonid levels (see Arismendi et al., 2009). Our study offers further evidence of the highly adaptable nature of rainbow trout and baseline demographic information that are needed to effectively manage rainbow trout in southern Chile.

Acknowledgements. This work was funded by Fondo Nacional de Desarrollo Regional (FNDR X Región), Fondo de Investigación Pesquera FIP 2000-24, and FONDECYT 1020183. Brooke Penaluna, Douglas Bateman, Regis Céréghino, and one anonymous reviewer provided insightful comments to improve the manuscript. I.A. was supported by Comision Nacional de Ciencia y Tecnologia of Chile (CONICYT) during his doctoral research.

\section{References}

Arismendi I. and Nahuelhual L., 2007. Non-native salmon and trout recreational fishing in Lake Llanquihue, southern Chile: Economic benefits and management implications. Rev. Fish. Sci., 15, 311-325. 
Arismendi I., Soto D., Penaluna B., Jara C., Leal C. and LeónMuñoz J., 2009. Aquaculture, non-native salmonid invasions, and associated declines of native fishes in lakes of the northern Chilean Patagonia. Freshwater Biol., 54, $1135-1147$.

Basulto S., 2003. El Largo viaje de los salmones: una crónica olvidada, Propagación y cultivo de especies acuáticas en Chile, Editorial Maval Ltda, Santiago, 299 p.

Behnke R.J., 1992. Native trout of western North America, American Fisheries Society (AFS) Monograph 6, American Fisheries Society, Bethesda, MD, 275 p.

Campos H., 1986. Productividad íctica de ríos y lagos Araucanos. In: Vila I. and Fagetti E. (eds.), Trabajos presentados al Taller Internacional sobre ecología y manejo de peces en lagos y embalses, Santiago, Chile, 5-10 de noviembre de 1984, COPESCAL Doc. Téc. 4, 237 p.

Campos H., Steffen W., Agüero G., Parra O. and Zuñiga L., 1988. Limnological study of Lake Llanquihue (Chile), morphometry, physics, chemistry, plankton and primary productivity. Arch. Hydrobiol., Suppl., 81, 37-67.

Chugunova N.I., 1959. Age and growth studies in fish. A systematic guide for ichthyologist (Translated from Russian), National Science Foundation, Washington, DC, USA, Israel Programs for Scientific Translations, Jerusalem (1963), $132 \mathrm{p}$.

Crawford S.S., 2001. Salmonine introductions to the Laurentian Great Lakes: an historical review and evaluation of ecological effects. Canadian Special Publication of Fisheries and Aquatic Sciences, 132, 205 p.

Crawford S.S. and Muir A.M., 2008. Global introductions of salmon and trout in the genus Oncorhynchus: 1870-2007. Rev. Fish. Biol. Fisher., 18, 313-344.

Davis N.D. and Light J.T., 1985. Steelhead age determination techniques, Fisheries Research Institute, Technical Report FRI-UW-8506, University of Washington, Seattle, $41 \mathrm{p}$.

Dedual M., Maxwell I.D., Hayes J.W. and Strickland R.R., 2000. Distribution and movements of brown (Salmo trutta) and rainbow trout (Oncorhynchus mykiss) in Lake Otamangakau, Central North Island, New Zealand. N. Z. J. Mar. Fresh., 34, 615-627.

Fraser C.M., 1916. Growth of the spring salmon. Am. Fish. Soc., 1915, 29-39.

Graynoth E., 1996. Determination of the age of brown and rainbow trout in a range of New Zealand lakes. Mar. Freshwater Res., 47, 749-756.

Hayes J.W., 1988. Mortality and growth of juvenile brown and rainbow trout in a lake inlet nursery stream. N. Z. J. Mar. Freshw. Res., 22, 169-179.

Isermann D.A. and Knight C., 2005. A computer program for age-length keys incorporating age assignment to individual fish. N. Am. J. Fish. Manage., 25, 1153-1160.

Lee R.M., 1920. A review of the methods of age and growth determination in fishes by means of scales, Fishery Investigations Series Vol. 4, Marine Fisheries, Great Britain Ministry of Agriculture, Fisheries and Food, London, $32 \mathrm{p}$.

Lindsay C.C., Northcote T.G. and Hartman G.F., 1959. Homing of rainbow trout to inlet and outlet spawning streams at Loon Lake, British Columbia. J. Fish. Res. Board Can., 16, 695-719.

Marr S.M., Marchetti M.P., Olden J.D., Garcia-Berthou E., Morgan D.L., Arismendi I., Day J.A., Griffiths C.L. and
Skelton P.H., 2010. Freshwater fish introductions in mediterranean-climate regions: are there commonalities in the conservation problem? Divers. Distrib., 16, 606619.

Mellina E., Hinch S.G., Mackenzie K.D. and Pearson G., 2005. Seasonal movement patterns of stream-dwelling rainbow trout in north-central British Columbia, Canada. Am. Fish. Soc., 134, 1021-1037.

Niemeyer H. and Cereceda P., 1984. Hidrografía. Colección Geográfica de Chile, Tomo VIII, Instituto Geográfico Militar (IGM), Santiago, Chile, 320 p.

Northcote T.G., 1962. Migratory behaviour of juvenile rainbow trout, Salmo gairdneri, in outlet and inlet streams of Loon Lake, British Columbia. J. Fish. Res. Board Can., 19, 201-270.

Northcote T.G., 1992. Migration and residency in stream salmonids: some ecological considerations and evolutionary consequences. Nord. J. Fresh. Res., 67, 5-17.

Northcote T.G., 1997. Potamodromy in Salmonidae-living and moving in the fast lane. N. Am. J. Fish. Manage., 17, $1029-1045$.

Palma R., 1996. Ensambles de peces en el Lago Llanquihue y su respuesta frente a la perturbación producida por la salmonicultura, Tesis de Magister en Ciencias con Mención en Limnología, Universidad Austral de Chile, Facultad de Ciencias, Valdivia, $93 \mathrm{p}$.

Pascual M., Bentzen P., Riva-Rossi C., Mackey G., Kinnison M.T. and Walker R., 2001. First documented case of anadromy in a population of introduced rainbow trout in Patagonia, Argentina. Am. Fish. Soc., 130, 53-67.

Quinn T.P. and Myers K.W., 2004. Anadromy and the marine migrations of Pacific salmon and trout: Rounsefell revisited. Rev. Fish Biol. Fisher., 14, 421-442.

Rabe F.W., 1967. Age and growth of rainbow trout in four Alpine Lakes. Northwest Sci., 41, 12-22.

Riva-Rossi C., Pascual M.A., Babaluk J.A., García-Asorey M. and Halden N.M., 2007. Intra-population variation in anadromy and reproductive life span in rainbow trout introduced in the Santa Cruz River, Argentina. J. Fish Biol., 70, 1-18.

Rosenau M., 1991. Natal-stream rearing in three populations of rainbow trout in Lake Taupo, New Zealand. N. Z. J. Mar. Fresh., 25, 81-91.

Sakai M. and Espinos A., 1994. Repeat homing and migration of rainbow trout to the inlet and outlet spawning streams in a Patagonian lake, Argentina. Fisheries Sci., 60, 137-142.

Satterthwaite W.H., Beakes M.P., Collins E.M., Swank D.R., Merz J.E., Titus R.G., Sogard S.M. and Mange M., 2010. State-dependent life history models in a changing (and regulated) environment: steelhead in the California Central Valley. Evol. Appl., 3, 221-243.

Seelbach P.W., 1993. Population biology of steelhead in a stableflow, low-gradient tributary of lake Michigan. Am. Fish. Soc., 122, 179-198.

Soto D., Arismendi I., Sanzana J. and Barrera V., 2001. Evaluación del potencial biológico de la pesca deportiva en la décima región, Informe Técnico FNDR X Región, Chile, $320 \mathrm{p}$.

Soto D., Arismendi I. and Solar I., 2002. Estudio del ciclo reproductivo de las principales especies objetivo de la pesca 
deportiva en la X Región, Proyecto FIP 2000-24, Valparaíso, Chile, 98 p.

Soto D., Arismendi I., González J., Sanzana J., Jara F., Jara C., Guzmán E. and Lara A., 2006. Southern Chile, trout and salmon country: invasion patterns and threats for native species. Rev. Chil. Hist. Nat., 79, 97-117.
Thomasson K., 1963. Araucanian Lakes. Plankton studies in north Patagonia with notes on terrestrial vegetation. Acta Phytogeogr. Sue., 47, 1-141.

Youngs W.D. and Oglesby R.T., 1972. Cayuga Lake: Effects of explotaition and introductions on the salmonid community. J. Fish. Res. Board Can., 29, 787-794. 